\title{
Position of the Bariatric and Metabolic Surgery Section of the Polish Association for the Study on Obesity on the use of pharmacotherapy to support the treatment of obesity before and after surgery
}

\author{
Stanowisko Sekcji Chirurgii Bariatrycznej i Metabolicznej \\ Polskiego Towarzystwa Badań nad Otyłością w sprawie stosowania \\ farmakoterapii wspomagającej leczenie otyłości \\ w okresie przed- i pooperacyjnym
}

\begin{abstract}
Mariusz Wyleżołำ Magdalena Olszanecka-Glinianowicz²
${ }^{1}$ II Department and Clinic of General, Vascular, and Oncology Surgery, II Medical Faculty, Warsaw Medical University, Warsaw, Poland

${ }^{2}$ Health Promotion and Obesity Management Unit, Department of Pathophysiology, Medical University of Silesia, Katowice, Poland
${ }^{1}$ II Katedra i Klinika Chirurgii Ogólnej, Naczyniowej i Onkologicznej, II Wydział Lekarskiego Warszawskiego Uniwersytetu Medycznego, Warszawa, Polska
2Zakład Promocji Zdrowia i Leczenia Otyłości, Katedra Patofizjologii Śląskiego Uniwersytetu Medycznego w Katowicach, Polska
\end{abstract}

The position is based on current literature data and presents the state of knowledge on the date of the analysis. It may be updated if new research results are published.

Stanowisko powstało na podstawie literatury i przedstawia stan wiedzy na ww. temat na dzień przeprowadzenia analizy. Może ono ulec aktualizacji w przypadku pojawienia się wyników nowych istotnych badań.

\section{Definition of the disease, factors influencing its progress, and its health effects}

Obesity is a chronic, multifactorial disease with no tendency for spontaneous recurrence and with a tendency to recur. The lack of effective treatment for obesity is best at the stage of overweight, leading to progression of the disease to its third degree, called extreme or fatal obesity (BMI $\geq 40 \mathrm{~kg} / \mathrm{m}^{2}$ ). Regardless of the original cause of the disease, excessive fat deposition in the body always carries a positive energy balance, that is, excess energy consumed over the expended. It should also be noted that obesity is increasingly seen as a psychosomatic disease, because in many cases, especially in patients with stage III disease, eating disorders such as binge eating syndrome, night-time eating syndrome, or food addiction are diagnosed [1-5].

\section{Definicja choroby, czynniki wpływające na jej postęp i jej skutki zdrowotne}

Otyłość jest chorobą przewlekłą o wieloczynnikowym podłożu, bez tendencji do samoistnego ustępowania i z tendencją do nawrotów. Brak skutecznego leczenia otyłości, najlepiej już na etapie nadwagi, prowadzi do postępu choroby aż do jej III stopnia, nazywanego otyłością olbrzymią lub śmiertelną (BMI $\geq 40 \mathrm{~kg} / \mathrm{m}^{2}$ ). Niezależnie od pierwotnej przyczyny choroby do nadmiernego odkładania się tkanki tłuszczowej w organizmie zawsze prowadzi dodatni bilans energetyczny, czyli nadmiar energii pobranej nad wydatkowaną. Należy również podkreślić, że coraz częściej otyłość postrzegana jest jako choroba o podłożu psychosomatycznym, gdyż w wielu przypadkach, zwłaszcza w grupie chorych z III stopniem zaawansowania, rozpoznaje się takie zaburzenia odżywiania, jak 
Because no country in the world has a well-functioning system of comprehensive treatment of obesity, and patients often use advice and methods of fighting obesity that have little to do with treatment based on modern medical knowledge, the proportion of patients with the most advanced stages of obesity is growing steadily. Regardless of the region of the world, the proportion of patients with grade III obesity is higher among women than among men [6]. This can be attributed both to the higher prevalence of eating disorders and atypical depressive disorders among women, but also to the fact that women are more likely to use a "miracle diet" or unprofessional diet advice in places that offer fast results, as desired by the patient.

As the disease progresses, the number of complications increases, the quality of life decreases, and the risk of disability and premature death increases. The costs of health care (direct costs) and indirect costs also increase - medical exemptions, early pensions, overtime in the working-age population, and the care of others [7]. Therefore, for both individual and social reasons, it is important to treat obesity effectively.

\section{What should be understood as effective treatment of obesity?}

The most important aspect of defining effective treatment for obesity is achieving weight loss and long-term lack of its re-growth. In addition, effective treatment for obesity is not only about achieving weight reduction, but also reducing the risk of developing obesity complications, or gaining at least an improvement and preferably remitting already existing complications, and thereby reducing the risk of death, extending life, and improving its quality. It should also be stressed that all these goals should be achieved with minimising the risk of undesirable effects of treatment. In addition, long-term treatment is required to achieve these goals [8]. Obese patients, regardless of the used method, are never completely cured because if they return to their earlier lifestyle, they will regain weight again in a short time. Understanding this fact by both physicians and patients is the key to longterm results.

\section{How can we successfully treat obesity?}

Effective treatment of obesity requires a comprehensive and personalised approach to the patient. Therefore, according to modern medical knowledge based on the results of randomised trials and meta-analysis based on the individual clinical situation, a wide range of options including diet and physical activity treatment, behavioural therapy, psychotherapy, pharmacotherapy zespół kompulsywnego jedzenia, zespół nocnego jedzenia czy nałogowe jedzenie [1-5].

W żadnym kraju świata nie funkcjonuje sprawnie działający system kompleksowego leczenia otyłości, dlatego chorzy często korzystają z porad i metod walki z otyłością, które mają niewiele wspólnego $\mathrm{z}$ leczeniem opartym na współczesnej wiedzy medycznej. W związku z tym sukcesywnie rośnie odsetek chorych z najbardziej zaawansowanymi stadiami otyłości. Niezależnie od rejonu świata odsetek chorych na otyłość III stopnia jest większy wśród kobiet niż wśród mężczyzn [6]. Można to przypisać zarówno częstszemu występowaniu zaburzeń odżywiania i atypowych zaburzeń depresyjnych wśród kobiet, jak i temu, że kobiety częściej stosują tzw. diety cud lub korzystają z nieprofesjonalnych porad dietetycznych $\mathrm{w}$ miejscach, które oferują szybkie rezultaty zgodnie z oczekiwaniami chorego.

Wraz z nasilaniem się choroby rośnie liczba jej powikłań, obniża się jakość życia i zwiększa się ryzyko wystąpienia niepełnosprawności oraz przedwczesnej śmierci. Rosną również istotnie koszty bezpośrednie (wynikające z opieki zdrowotnej) oraz pośrednie - zwolnienia lekarskie, wczesne renty, nadumieralność w populacji osób w wieku produkcyjnym oraz opieka innych osób [7]. Dlatego ze względów zarówno indywidualnych, jak i społecznych ważne jest skuteczne leczenie otyłości.

\section{Co należy rozumieć pod pojęciem skutecznego leczenia otyłości?}

Najważniejszym aspektem zdefiniowania skutecznego leczenia otyłości jest uzyskanie redukcji masy ciała i długoterminowy brak jej ponownego przyrostu. Ponadto skuteczne leczenie otyłości to nie tylko uzyskanie redukcji masy ciała, lecz także obniżenie ryzyka rozwoju powikłań otyłości lub co najmniej poprawy, a najlepiej remisji w zakresie już istniejących powikłań, a co za tym idzie zmniejszenie ryzyka śmierci, wydłużenie czasu życia i poprawa jego jakości. Należy także podkreślić, że wszystkie te cele należy osiągnąć przy jednoczesnej minimalizacji ryzyka działań niepożądanych zastosowanego leczenia. Poza tym dla osiągnięcia tych celów konieczne jest długotrwałe leczenie [8]. Chory na otyłość niezależnie od zastosowanej metody nigdy nie jest do końca wyleczony, ponieważ jeżeli powróci do wcześniejszego stylu życia w krótkim czasie, dojdzie do ponownego przyrostu masy ciała. Zrozumienie tego faktu zarówno przez lekarzy, jak i pacjentów stanowi klucz do uzyskania długotrwałych rezultatów.

\section{Jak można skutecznie leczyć otyłość?}

Skuteczne leczenie otyłości wymaga kompleksowego i zindywidualizowanego podejścia do chorego. Dlatego też zgodnie ze współczesną wiedzą medyczną opartą na wynikach badań z randomizacją i metaanaliz, w zależności od 
as well as surgical treatment are used to treat obesity. The method of treatment for obesity or a combination of methods should be selected individually depending on the nutritional status, the occurrence of obesity complications, and the patient's psychological problems [8]. It is obvious that a physician cannot use methods of treating obesity, whose effectiveness and safety have not been confirmed by scientific findings, even if they seem to be effective.

Because obesity is a disease for its treatment, it is the doctor's responsibility, and he/she supervises and coordinates the work of the other team members: the psychologist, dietitian, and physiotherapist. Doctors treating obesity are also responsible for collaborating with a bariatric and metabolic surgeon and other specialists treating obesity complications [9].

The results of previous studies indicate that conservative treatment of obesity, especially in the third degree, is not very effective, especially in the aspect of obtaining long-term effects. According to the results of current research and meta-analysis, surgical treatment is believed to be the only method of treating thirddegree obesity with proven efficacy [10-13]. However, it should be stressed that the effectiveness of conservative treatment for obesity is significantly reduced due to the lack of access to comprehensive specialist treatment and pharmacotherapy. None of the published studies on the efficacy of conservative treatment for obesity exclude the assessment of personalised comprehensive treatment using all recommended methods, and most studies address only treatment limited to diet and behavioural therapy and increased physical activity.

\section{Why surgical treatment may be ineffective?}

Long-term observations of patients treated for obesity show that some of them are re-growing [14]. Ineffective surgical treatment may have a multifactorial substrate. Ineffective surgical treatment may have a multifactorial substrate. The first and most important factor is the incorrect qualification for surgical treatment. It should be emphasised that according to Polish recommendations in the field of bariatric and metabolic surgery for absolute contraindications to surgical treatment of obesity including among others alcohol or drug dependence, a lack of ability to remain in longterm postoperative treatment, and relative contraindications include weight gain in the immediate preceding period operations. In these recommendations, as absolute contraindications also should be mentioned mental illnesses that are not controlled despite treatment and pharmacotherapy. Mental illnesses also include eating rozpatrywanej indywidualnie sytuacji klinicznej, w leczeniu otyłości wykorzystuje się szeroki wachlarz opcji obejmujących leczenie dietetyczne i ruchowe, terapię behawioralną, psychoterapię, farmakoterapię, jak również leczenie chirurgiczne. Metodę leczenia otyłości lub połączenia metod należy dobierać indywidualnie w zależności od stanu odżywienia, występowania powikłań otyłości oraz problemów psychologicznych pacjenta [8]. Lekarz nie może stosować metod leczenia, których skuteczności i bezpieczeństwa nie potwierdzono przez wyniki badań naukowych, nawet jeżeli pozornie wydają się one skuteczne.

Otyłość jest chorobą, dlatego za jej leczenie odpowiada lekarz i to on nadzoruje i koordynuje pracę pozostałych członków zespołu - psychologa, dietetyka i rehabilitanta. Lekarz leczący otyłość zachowawczo odpowiada również za współpracę z chirurgiem bariatrycznym i metabolicznym oraz z innymi specjalistami leczącymi powikłania otyłości [9].

Wyniki dotychczasowych badań wskazują, że zachowawcze leczenie otyłości, a przede wszystkim otyłości III stopnia, jest mało skuteczne, zwłaszcza w aspekcie uzyskania długoterminowych efektów. Zgodnie z wynikami dotychczasowych badań i metaanaliz uważa się, że leczenie chirurgiczne jest jedyną metodą leczenia otyłości III stopnia o udowodnionej skuteczności [10-13]. Należy jednak podkreślić, że skuteczność zachowawczego leczenia otyłości jest znacznie ograniczona $\mathrm{z}$ powodu braku dostępności do specjalistycznej, kompleksowej terapii oraz farmakoterapii. Żadna z publikowanych analiz dotyczących skuteczności zachowawczego leczenia otyłości nie uwzględnia oceny zindywidualizowanego kompleksowego leczenia $\mathrm{z}$ zastosowaniem wszystkich rekomendowanych metod, a większość badań odnosi się wyłącznie do leczenia ograniczającego się do stosowania terapii dietetycznej i behawioralnej oraz zwiększenia aktywności fizycznej.

\section{Dlaczego leczenie chirurgiczne może być nieskuteczne?}

Wieloletnie obserwacje chorych leczonych chirurgicznie z powodu otyłości pokazują, że u części z nich dochodzi do ponownego przyrostu masy ciała [14]. Brak skuteczności tego typu leczenia może mieć wieloczynnikowe podłoże. Pierwszą i najważniejszą przyczyną jest nieprawidłowa kwalifikacja do leczenia operacyjnego. Należy podkreślić, że zgodnie z polskimi rekomendacjami w zakresie chirurgii bariatrycznej i metabolicznej do bezwzględnych przeciwwskazań do leczenia operacyjnego otyłości należą m.in. uzależnienie od alkoholu lub narkotyków, brak możliwości pozostawania w długotrwałym leczeniu pooperacyjnym, natomiast do przeciwwskazań względnych należy zwiększenie masy ciała w okresie bezpośrednio poprzedzającym operację. W tych rekomendacjach jako przeciwwskazanie bezwzględne wymieniono 
disorders. Qualification for surgical treatment of such patients, especially with eating disorders, may be the main reason for the ineffectiveness of this treatment. It has been observed that patients undergoing surgery may develop depression after the operation or may develop other addictions such as alcoholism [14]. This may be due to the function of the reward system and the replacement of the stimulus with other stimulant, e.g. alcohol.

It should also be stressed that the cause of ineffectiveness may also be the patient's recognition that he/she has been fully cured and that he/she does not need further conservative treatment. Patients after surgery require long-term medical, dietetic, and psychological care to strengthen the therapeutic effect and prevent late complications [15].

\section{Preparation for surgical treatment}

According to Polish recommendations in the field of bariatric and metabolic surgery, the optimal preparation time for surgical treatment is 6-12 months, and at this time the patient should have a minimum of three visits. Recommendations do not specify what should be included in these visits [15]. In the opinion of PASO, during these visits, the patient should not only be acquainted with the planned surgical procedure and its beneficial consequences and possible complications, but if he/she has not previously been professionally treated conservatively, such treatment should be applied using all available methods described above individually selected for the needs of the patient.

The quoted recommendations say that a patient should consider presenting the requirements for a significant reduction in body weight before surgery [15]. Numerous studies indicate that this should be a condition of eligibility for surgery because preoperative weight reduction reduces operational risk and is a confirmation that the patient has made a conscious decision about the merits of surgical treatment $[16,17]$. However, please note that the role of the physician is to assist the patient with all available methods.

\section{Available drugs supporting the treatment of obesity}

On the Polish pharmaceutical market there are currently two of the three drugs supporting the treatment of obesity registered in the European Union. These are orlistat (Xenical), which has been known for 20 years, and a combination preparation containing naltrexone and bupropion (Mysimba). The use of orlistat for local gastrointestinal motility has a limited range również choroby psychiczne niepoddające się kontroli mimo leczenia i farmakoterapii. Do chorób psychicznych należy również zaliczyć zaburzenia odżywiania. Zakwalifikowanie do leczenia chirurgicznego takich chorych, zwłaszcza z zaburzeniami odżywiania, może być główną przyczyną nieskuteczności tego leczenia. Obserwowano, że u chorych operowanych może po zabiegu dochodzić do rozwoju depresji lub mogą rozwijać się inne nałogi, np. alkoholizm [14]. Może to wynikać z funkcji układu nagrody i zastępowania bodźca, jakim jest jedzenie, innym czynnikiem stymulującym, np. alkoholem.

Należy także podkreślić, że przyczyną nieskuteczności może być również uznanie przez chorego, że został w pełni wyleczony i nie jest mu potrzebne dalsze leczenie zachowawcze. Chory po leczeniu chirurgicznym wymaga wieloletniej opieki lekarskiej, dietetycznej i psychologicznej w celu wzmocnienia efektu terapeutycznego oraz zapobiegania odległym powikłaniom [15].

\section{Przygotowanie do leczenia chirurgicznego}

Zgodnie z polskimi rekomendacjami w zakresie chirurgii bariatrycznej i metabolicznej optymalny czas przygotowania do leczenia chirurgicznego wynosi 6-12 miesięcy i w tym okrsie chory powinien odbyć minimum 3 wizyty. Rekomendacje nie precyzują, co powinno wchodzić w zakres tych wizyt [15]. W opinii PTBO w czasie tych wizyt pacjent powinien nie tylko zapoznać się z planowanym zabiegiem operacyjnym i jego korzystnymi konsekwencjami, lecz także z ewentualnymi powikłaniami, a jeżeli nie był wcześniej profesjonalnie leczony zachowawczo, należy takie leczenie zastosować $\mathrm{z}$ wykorzystaniem wszystkich dostępnych metod opisanych powyżej, dobranych indywidualnie do potrzeb pacjenta.

$\mathrm{Z}$ cytowanych rekomendacji wynika, że warto rozważyć przedstawienie choremu wymogów dotyczących znacznego zmniejszenia masy ciała przed operacją [15]. Liczne wyniki badań wskazują wręcz, że powinien być to warunek kwalifikacji do operacji, ponieważ przedoperacyjna redukcja masy ciała zmniejsza ryzyko operacyjne oraz jest potwierdzeniem podjęcia przez chorego świadomej decyzji odnośnie do zasadności leczenia operacyjnego $[16,17]$. Należy jednak pamiętać, że rolą lekarza jest udzielenie choremu pomocy $\mathrm{w}$ tym zakresie wszystkimi dostępnymi metodami.

\section{Dostępne leki wspomagające leczenie otytości}

Na polskim rynku farmaceutycznym dostępne są obecnie dwa $\mathrm{z}$ trzech zarejestrowanych w Unii Europejskiej leków wspomagających leczenie otyłości. Są to znany od 20 lat 
and may be effective in patients who prefer fatty foods. This drug reduces the absorption of fats, which reduces the energy delivery but does not affect the central regulation of food intake (feeling hunger, satiety, and appetite) $[18]$.

Mysimba is a combined preparation containing two active substances: bupropion hydrochloride and naltrexone hydrochloride. Throughout the world, including in Poland, these substances have been used as monotherapy in other indications for many years. Bupropion is an antidepressant from the dopamine and noradrenaline reuptake inhibitors group (NDRI). It is also an incompetent nicotine receptor antagonist. Naltrexone is an opioid receptor $\mu$ antagonist, to a lesser extent $\kappa$ receptors, and to the smallest $\lambda$ receptors. The combination of buproprion hydrochloride and naltrexone hydrochloride is justified because of their hyperaddressive synergy on the effect on food, i.e. when the simultaneous application of two or more active substances is stronger than the sum of the effects of the individual active substances (so-called potentiation/enhancement effect). Both of these substances act on the same anatomical regions of the central nervous system - the arcuate nucleus of the hypothalamus (centres of satiety and hunger) and the mesolimbic dopaminergic reward system (feeling appetite - seeking food not to satisfy hunger but to enjoy pleasure from eating it) [19-24].

Bupropion in the hypothalamic arcuate nucleus stimulates the activity of pro-opiomelanocortin-releasing neurons (POMC) and CART, which in turn stimulates $\alpha$-melanotropin ( $\alpha-\mathrm{MSH})$ release which binds to melanocortin receptors type 4 (MC4-R) and stimulates sensation of satiety. In addition, POMC stimulates release of $\beta$-endorphin, which in the negative feedback loop through $\mu$ opioid receptors blocks POMC neuron activity. Naltrexone removes this blockage, prolonging the bupropion action stimulating satiety. In addition, the experimental studies revealed that stimulation of the POMC system increases energy expenditure in the form of thermogenesis. Inhibiting the reuptake of dopamine and noradrenaline by bupropion and blocking the $\mu$ opioid receptors by naltrexone stimulates the reward system and reduces the desire to eat for pleasure $[25,26]$.

Clinical studies have demonstrated the hyper-additional (potentiating) effect of the combination of bupropion hydrochloride and naltrexone hydrochloride on weight loss [27-30]. It should be stressed that clinical trials have also confirmed the efficacy and safety of this drug in patients with II and III grade obesity. During 56 weeks of treatment, at least 5\% weight loss was achieved in 54\% and $49 \%$, respectively, and at least $10 \%$ weight loss in $32 \%$ and $22 \%$, respectively [31]. orlistat (Xenical) i preparat złożony zawierający naltrekson i bupropion (Mysimba). Orlistat ze względu na lokalny mechanizm działania w przewodzie pokarmowym ma ograniczony zakres wskazań i może być skuteczny u chorych preferujących tłuste pokarmy. Lek ten zmniejsza wchłanianie spożytych tłuszczów, przez co zmniejsza dowóz energii, nie wywiera jednak wpływu na ośrodkową regulację poboru pokarmu (uczucie głodu, sytości i apetytu) [18].

Mysimba jest preparatem złożonym zawierającym dwie substancje czynne - chlorowodorek bupropionu i chlorowodorek naltreksonu. Na świecie, w tym w Polsce, substancje te są stosowane w monoterapii w innych wskazaniach od wielu lat. Bupropion jest lekiem przeciwdepresyjnym z grupy inhibitorów wychwytu zwrotnego dopaminy i noradrenaliny (NDRI). Jest także niekompetycyjnym antagonistą receptorów nikotynowych. Naltrekson jest antagonistą receptora opioidowego $\mu, \mathrm{w}$ mniejszym stopniu receptorów $\kappa$, a w najmniejszym stopniu receptorów $\lambda$. Połączenie chlorowodorku buproprionu i chlorowodorku naltreksonu jest uzasadnione z powodu ich synergii hiperaddycyjnej w przypadku wpływu na pobór pokarmu, czyli sytuacji, gdy jednoczesne zastosowanie dwóch lub więcej substancji czynnych wykazuje efekt silniejszy niż wynikający z sumy działań poszczególnych substancji czynnych (tzw. potencjalizacja lub potęgowanie efektu). Obydwie te substancje działają na te same regiony anatomiczne ośrodkowego układu nerwowego - jądro łukowate podwzgórza (ośrodki sytości i głodu) i mezolimbiczny dopaminergiczny układ nagrody (uczucie apetytu - poszukiwanie konkretnego pokarmu nie w celu zaspokojenia głodu, ale odczucia przyjemności z jego spożycia) [19-24].

Bupropion w jądrze łukowatym podwzgórza stymuluje aktywność neuronów wydzielających proopiomelanokortynę (POMC) oraz CART, a te z kolei pobudzają uwalnianie a-melanotropiny (a-MSH), która wiążąc się z receptorami melanokortyny typu 4 (MC4-R), stymuluje odczucie sytości. Dodatkowo POMC stymuluje uwalnianie $\beta$-endorfiny, która w pętli ujemnego sprzężenia zwrotnego przez receptory opioidowe $\mu$ blokuje aktywność neuronów POMC. Naltrekson znosi to blokowanie, przedłużając stymulujące sytość działanie bupropionu. Poza tym w badaniach eksperymentalnych wykazano, że stymulacja układu POMC zwiększa wydatek energetyczny w postaci termogenezy. Hamowanie wychwytu zwrotnego dopaminy i noradrenaliny przez bupropion oraz blokowanie receptorów opioidowych $\mu$ przez naltrekson stymuluje układ nagrody i zmniejsza chęć jedzenia w celu odczucia przyjemności $[25,26]$.

W badaniach klinicznych udowodniono wpływ synergii hiperaddycyjnej (potencjalizacji) połączenia chlorowodorku bupropionu i chlorowodorku naltreksonu na redukcję masy ciała [27-30]. Należy podkreślić, że badania kliniczne potwierdziły również skuteczność i bezpieczeństwo stosowania tego leku u chorych z II i III stopniem otyłości. 


\section{When should a bariatric surgeon consider the use of pharmacotherapy?}

1. In the preoperative period to facilitate the patient to achieve weight loss and improve co-operation, and as a component of treatment of eating disorders in combination with psychotherapy.

2. In patients who are disqualified from surgical treatment for which there are no contraindications for pharmacotherapy.

3. In patients undergoing surgical treatment, who do not have sufficient therapeutic effect or are experiencing weight gain again and the diagnosis does not justify performing the revision surgery.

4. In addition, taking into account the early and late risk associated with bariatric surgery, the patient should be informed of new possibilities for the pharmacological treatment of obesity and allowed to make a conscious choice. Patients should be informed about the risks associated with surgical treatment and the cost of pharmacotherapy and the need for long-term use (minimum six months, and optimally as long as the patient tolerates the treatment well). It should be noted that according to current knowledge, pharmacotherapy for the treatment of obesity should be used chronically.
W trakcie 56 tygodni leczenia co najmniej 5-procentową redukcję masy ciała uzyskano odpowiednio u 54\% i 49\% chorych, a co najmniej 10-procentową redukcję masy ciała odpowiednio u $32 \%$ i $22 \%$ [31].

\section{Kiedy chịrurg bariatra powinien rozważyć zastosowanie farmakoterapii?}

1. W okresie przedoperacyjnym w celu ułatwienia choremu uzyskania redukcji masy ciała oraz polepszenia współpracy, a także jako element leczenia zaburzeń odżywiania w połączeniu z psychoterapią.

2. U chorych niezakwalifikowanych do leczenia operacyjnego, u których nie występują przeciwwskazania do stosowania farmakoterapii.

3. U chorych poddanych leczeniu operacyjnemu, u których nie uzyskuje się dostatecznego efektu terapeutycznego lub u których obserwuje się ponowny przyrost masy ciała, a przeprowadzona diagnostyka nie uzasadnia wykonania operacji rewizyjnej.

4. Ponadto, biorąc pod uwage ryzyko wczesne i późne związane z przeprowadzeniem operacji bariatrycznej, należy poinformować chorego o nowych możliwościach farmakologicznego leczenia otyłości i pozwolić mu na świadome dokonanie wyboru. Chory powinien zostać poinformowany o ryzyku związanym z leczeniem operacyjnym oraz o kosztach farmakoterapii i konieczności jej długotrwałego stosowania (minimum 6 miesięcy, a optymalnie tak długo jak chory dobrze toleruje leczenie). Należy podkreślić, że zgodnie $\mathrm{z}$ aktualną wiedzą farmakoterapia w leczeniu otyłości powinna być stosowana przewlekle.

\section{Disclosure/Oświadczenie}

Authors report no conflict of interest./Autorzy nie zgłaszają konfliktu interesu.

\section{References/Piśmiennictwo}

1. Herpertz S. [Obesity is more than an eating disorder-the multidimensional perspective of a pandemia]. Z Psychosom Med Psychother 2008; 54: 4-31.

2. Hauner H. [Obesity-a somatic or psychological condition or both?]. Herz 2006; 31: 207-212.

3. Nicholls W, Devonport TJ, Blake M. The association between emotions and eating behaviour in an obese population with binge eating disorder. Obes Rev 2016; 17: 30-42.

4. Frey L, Riva M, Grosshans M, Mutschler J. [“Food addiction” as a possible risk factor for obesity]. Praxis (Bern 1994) 2016; 105: 397-404.

5. Obesity. Preventing and managing the global epidemic. Report of a WHO, Geneva 1998.

6. World Health Organization. Global Health Observatory data repository. Obesity. Dostęp: http://apps.who.int/gho/data/view.main.2450A; available at the date of October $10^{\text {th }}, 2016$.

7. Grossman RM. The economics of obesity. Public Interest 2004; 156: 110.

8. Yumuk V, Tsigos C, Fried M, et al. European Guidelines for Obesity Management in Adults. Obes Facts 2015; 8: 402-424.

9. Garvey WT, Mechanick JI, Brett EM, et al. American Association of Clinical Endocrinologist and College of Endocrinology Comprehensive Clinical Practice Guidelines for Medical Care of Patients with Obesity. Endocrine Practice, 2016; 22 (Suppl 3): 1-203.

10. Maggard MA, Shugarman LR, Suttorp M, et al. Meta-analysis: surgical treatment of obesity. Ann Intern Med 2005; 142: 547-559.

11. Buchwald H, Avidor Y, Braunwald E, et al. Bariatric surgery: a systematic review and meta-analysis. JAMA 2004; 292: 1724-1737. 
Position of the Bariatric and Metabolic Surgery Section of the Polish Association for the Study on Obesity on the use of pharmacotherapy to support the treatment of obesity before and after surgery Stanowisko Sekcji Chirurgii Bariatrycznej i Metabolicznej Polskiego Towarzystwa Badań nad Otyłością w sprawie stosowania farmakoterapii wspomagającej leczenie otyłości w okresie przed- i pooperacyjnym

12. Martins C, Strommen M, Stavne OA, et al. Bariatric surgery versus lifestyle interventions for morbid obesity - changes in body weight, risk factors and comorbidities at 1 year. Obes Surg 2011; 21: 841-849.

13. Hofso D, Nordstrand N, Johnson LK, et al. Obesity-related cardiovascular risk factors after weight loss: a clinical trial comparing gastric bypass surgery and intensive lifestyle intervention. Eur J Endocrinol 2010; 163: 735-745.

14. Sjöström L. Review of the key results from the Swedish Obese Subjects (SOS) trial - a prospective controlled intervention study of bariatric surgery. J Intern Med 2013; 273: 219-234.

15. Budzyński A, Major P, Głuszek S, et al. Polskie rekomendacje w zakresie chirurgii bariatrycznej i metabolicznej. Med Prakt Chirurgia 2016; 6: $13-25$

16. Benotti PN, Still CD, Wood GC, et al. Preoperative weight loss before bariatric surgery. Arch Surg 2009; 144: 1150-1155.

17. Livhits M, Mercado C, Yermilov I, et al. Does weight loss immediately before bariatric surgery improve outcomes: a systematic review. Surg Obes Relat Dis 2009; 5: 713-721.

18. McNeely W, Benfield P. Orlistat. Drugs 1998; 56: 241-250.

19. Dhillon S, Yang LP, Curran MP. Bupropion: a review of its use in the management of major depressive disorder. Drugs 2008; 68: 653-689.

20. Dwoskin LP, Rauhut AS, King-Pospisil KA, Bardo MT. Review of the pharmacology and clinical profile of bupropion, an antidepressant and tobacco use cessation agent. CNS Drug Rev 2006; 12: 178-207.

21. Foley KF, DeSanty KP, Kast RE. Bupropion: pharmacology and therapeutic applications. Expert Rev Neurother 2006; 6: 1249-1265.

22. Froehlich J, O'Malley S, Hyytia P, et al. Preclinical and clinical studies on naltrexone: what have they taught each other? Alcohol Clin Exp Res 2003; 27: 533-539.

23. Bodnar RJ. Endogenous opioids and feeding behavior: a 30-year historical perspective. Peptides 2004; 25: 697-725.

24. Levine AS, Billington CJ. Opioids as agents of reward-related feeding: a consideration of the evidence. Physiol Behav 2004; 82: 57-61.

25. Billes SK, Sinnayah P, Cowley MA. Naltrexone/bupropion for obesity: an investigational combination pharmacotherapy for weight loss. Pharmacol Res 2014; 84: 1-11.

26. Picciotto MR, Mineur YS. Nicotine, food intake, and activation of POMC neurons. Neuropsychopharmacology 2013; 38: 245.

27. Greenway FL, Fujioka K, Plodkowski RA, et al. Effect of naltrexone plus bupropion on weight loss in overweight and obese adults (COR-I): a multicentre, randomised, double-blind, placebo-controlled, phase 3 trial. Lancet 2010; 376: 595-605.

28. Apovian CM, Aronne L, Rubino D, et al. A randomized, phase 3 trial of naltrexone SR/bupropion SR on weight and obesity-related risk factors (COR-II) Obesity (Silver Spring) 2013; 21: 935-943.

29. Wadden TA, Foreyt JP, Foster GD, et al. Weight loss with naltrexone SR/bupropion SR combination therapy as an adjunct to behavior modification: the COR-BMOD trial. Obesity (Silver Spring) 2011; 19: 110-120.

30. Hollander P, Gupta AK, Plodkowski R, et al. Effects of naltrexone sustained-release/bupropion sustained-release combination therapy on body weight and glycemic parameters in overweight and obese patients with type 2 diabetes. Diabetes Care 2013; 36: 4022-4029.

31. Shan K, Halseth A, Apovian C. An integrated analysis of weight loss with combination prolonged-release Naltrexone/Bupropion therapy by BMI classification. ICO 2016 poster presentation. 